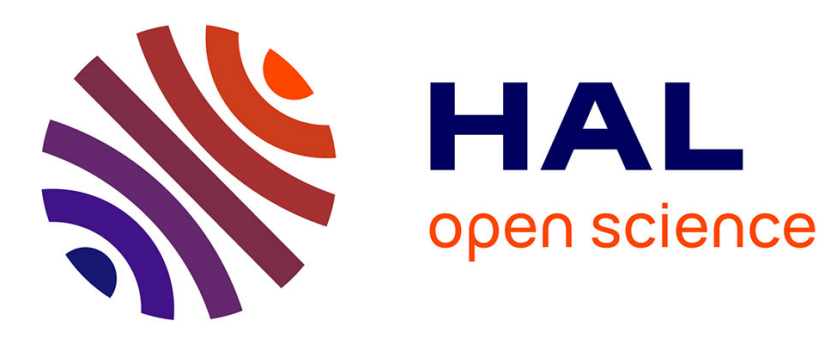

\title{
Induction Motors Thermal Monitoring by Means of Rotor Resistance Identification
}

\author{
Rachid Beguenane, Mohamed Benbouzid
}

\section{To cite this version:}

Rachid Beguenane, Mohamed Benbouzid. Induction Motors Thermal Monitoring by Means of Rotor Resistance Identification. IEEE Transactions on Energy Conversion, 1999, 14 (3), pp.566-570. hal01052317

\section{HAL Id: hal-01052317 https://hal.science/hal-01052317}

Submitted on 25 Jul 2014

HAL is a multi-disciplinary open access archive for the deposit and dissemination of scientific research documents, whether they are published or not. The documents may come from teaching and research institutions in France or abroad, or from public or private research centers.
L'archive ouverte pluridisciplinaire HAL, est destinée au dépôt et à la diffusion de documents scientifiques de niveau recherche, publiés ou non, émanant des établissements d'enseignement et de recherche français ou étrangers, des laboratoires publics ou privés. 


\section{Induction Motors Thermal Monitoring by Means of Rotor Resistance Identification}

\author{
R. Beguenane, Member, IEEE \\ School of Information Technology and Engineering \\ University of Ottawa \\ Ottawa, Ontario, Canada K1N 6N5 \\ beguenan@buddy.genie.uottawa.ca
}

\begin{abstract}
Rotor and stator temperature are of concern in both shortterm machine protection and in longer term condition monitoring for large induction machines. Especially, when operating with overload cycles, it is necessary to monitor rotor bars and stator winding temperatures to make sure that the temperature remains below prescribed limits. The purpose of this paper is to present a thermal monitoring technique, for induction motors steady-state operation, based on the rotor resistance identification. Experimental results, for a 4-kW four-pole squirrel cage induction motor, show the industrial viability of the proposed technique.
\end{abstract}

Keywords: Induction motors, thermal monitoring, steady-state operation, rotor resistance, resistance identification, stator voltage, stator current, stator excitation frequency, rotor speed.

\section{INTRODUCTION}

The use of comprehensive monitoring schemes for continuous assessment of the electrical and mechanical condition of rotating electrical machines is becoming increasingly important. A successful condition monitoring scheme on a machine would be capable of providing adequate warning of imminent failure of its critical components, both electrical and mechanical, and would enable preventive maintenance and repair work to be scheduled. Parameters presently monitored on induction machines include terminal voltage, current, rotor speed, etc. The parameters so monitored have been found capable of predicting and identifying stator ground and interturn faults, phase failure, stall, overload, bearing failure, rotor defects, shaft eccentricity but with varying degrees of success as summarized in [1-4].

Rotor temperature is given considerable importance in the design and protection of machines but has been left out of the conventional as well as the recently developed monitoring schemes. The function of a temperature monitor is taken over by other secondary monitoring systems. One obstacle appears to be the difficulties in accessing information from the rotor while the machine is in normal operation. The availability of a continuous temperature profile across the rotor can contribute much to a comprehensive condition monitor.

This paper describes an electrical model of the induction motor and the process by which the rotor resistance in that model is estimated from measurements of stator voltage, stator current, stator excitation frequency, and rotor speed. This is the basis for thermal monitoring of the induction motor steady-state operation.
M.E.H. Benbouzid, Member, IEEE

Groupe de Recherche sur l'Analyse et la Commande des Systèmes Unité Mixte de Recherche UPJV/ESIEE

7, Rue du Moulin Neuf - 80000 Amiens, FRANCE

Mohamed-El-Hackemi.Benbouzid@sc.u-picardie.fr

\section{ROTOR RESISTANCE IDENTIFICATION}

The method to be proposed is based on the proper selection of coordinate axes, namely the $d$-axis of the rotating frame is set to be coincident with the stator current vector [5].

It is well known that an induction motor can be represented by the following differential equations in $d-q$ axes fixed in the stator.

$$
\left[\begin{array}{c}
v_{s d} \\
v_{s q} \\
0 \\
0
\end{array}\right]=\left[\begin{array}{cccc}
R_{s}+s L_{s} & -\omega_{s} L_{s} & s M & -\omega_{s} M \\
\omega_{s} L_{s} & R_{s}+s L_{s} & \omega_{s} M & s M \\
s M & -\omega_{s l} M & R_{r}+s L_{r} & -\omega_{s l} L_{r} \\
\omega_{s l} M & s M & \omega_{s l} L_{r} & R_{r}+s L_{r}
\end{array}\right]\left[\begin{array}{c}
i_{s d} \\
i_{s q} \\
i_{r d} \\
i_{r q}
\end{array}\right]
$$

where

$$
\begin{array}{ll}
v_{s d}\left(v_{s q}\right) & =d \text {-axis }(q \text {-axis) stator voltage } \\
i_{s d}\left(i_{s q}\right) & =d \text {-axis }(q \text {-axis) stator current } \\
i_{r d}\left(i_{r q}\right) & =d \text {-axis }(q \text {-axis) rotor current } \\
R_{s},\left(R_{r}\right) & =\text { per phase stator (rotor) resistance } \\
L_{s},\left(L_{r}\right) & =\text { per phase stator (rotor) inductance } \\
M & =\text { per phase mutual inductance } \\
\omega_{s} & =\text { supply frequency } \\
\omega_{s l} & =\text { slip frequency, } \omega_{s l}=\omega_{s}-\omega_{r} \\
\omega_{r} & =\text { rotor frequency } \\
s & =\text { time derivative operator. }
\end{array}
$$

Equation (1) can be transformed as follows: we make the $d$-axis coincide and synchronously rotate with the stator current vector $I_{s}$. Thus it can simplified as

$$
\left[\begin{array}{c}
v_{s d} \\
v_{s q} \\
0 \\
0
\end{array}\right]=\left[\begin{array}{cccc}
R_{s}+s L_{s} & -\omega_{s} L_{s} & s M & -\omega_{s} M \\
\omega_{s} L_{s} & R_{s}+s L_{s} & \omega_{s} M & s M \\
s M & -\omega_{s l} M & R_{r}+s L_{r} & -\omega_{s l} L_{r} \\
\omega_{s l} M & s M & \omega_{s l} L_{r} & R_{r}+s L_{r}
\end{array}\right]\left[\begin{array}{c}
I_{s} \\
0 \\
i_{r d} \\
i_{r q}
\end{array}\right]
$$

In the case of steady-state operation, the following equation could be derived from (2). 
$\left[\begin{array}{c}v_{s d} \\ v_{s q} \\ 0 \\ 0\end{array}\right]=\left[\begin{array}{ccc}R_{s} & 0 & -\omega_{s} M \\ \omega_{s} L_{s} & \omega_{s} M & 0 \\ 0 & R_{r} & -\omega_{s l} L_{r} \\ \omega_{s l} M & \omega_{s l} L_{r} & R_{r}\end{array}\right]\left[\begin{array}{c}I_{s} \\ i_{r d} \\ i_{r q}\end{array}\right]$

Considering the last three rows of (3) and solving the resulting equations system, we get

$R_{r}=\sqrt{-\omega_{s l}^{2} L_{r}\left[\frac{\omega_{s} M^{2}}{\frac{v_{s q}}{I_{s}}-\omega_{s} L_{s}}+L_{r}\right]}$

To avoid time-consumed computations related to $d-q$ Park transformation, electrical quantities are expressed in the $\alpha-\beta$ axes fixed in the stator (Fig. 1). In this case, we get

$\left[\begin{array}{l}v_{s d} \\ v_{s q}\end{array}\right]=\frac{1}{I_{s}}\left[\begin{array}{cc}1 & 0 \\ 0 & -1\end{array}\right]\left[\begin{array}{l}P \\ Q\end{array}\right]$

where $\left\{\begin{array}{l}P=v_{s \alpha} i_{s \alpha}+v_{s \beta} i_{s \beta} \\ Q=v_{s \alpha} i_{s \beta}-v_{s \beta} i_{s \alpha}\end{array}\right.$

Using the simplified Park matrix to combine (5) and (6) into (4), we obtain a more suitable expression of the rotor resistance.

$R_{r}=\sqrt{\omega_{s l}^{2} L_{r}\left[\frac{\omega_{s} M^{2}}{\frac{Q}{I_{s}^{2}}+\omega_{s} L_{s}}-L_{r}\right]}$

We can now summarize the identification procedure of the rotor resistance as:

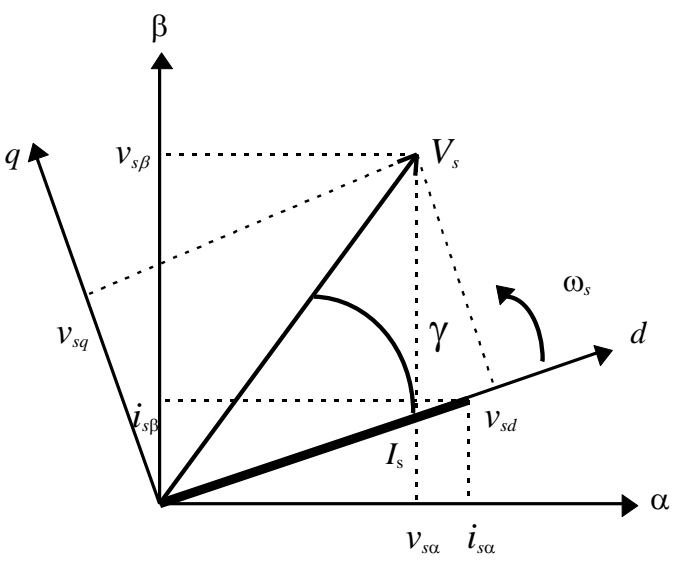

Fig. 1. Phasor diagram of stator voltage and current.
- Acquisition of the stator voltage, current, and motor speed: $v_{l s}, v_{2 s}, v_{3 s} ; i_{l s}, i_{2 s}, i_{3 s}$ and $\omega_{m}=\omega_{r} / p$.

- Computation of measured voltages and currents Park components: $v_{s \alpha}, v_{s \beta}$, and $i_{s \alpha}, i_{s \beta}$.

- Computation of the reactive power $Q$ by (6).

- Identification of $R_{r}$ by using formula (7).

\section{INDUCTION MOTOR THERMAL MONITORING}

It is easy to monitor rotor temperature from its resistance identification and then its temperature dependence, which is given by

$R=R_{0}[1+\alpha \Delta T]$

where $\quad R_{0}=$ resistance at reference temperature $T_{0}=25^{\circ} \mathrm{C}$

$\alpha=$ resistance temperature coefficient

$\Delta T=$ temperature increase.

The proposed identification method is unfortunately unable to identify the stator resistance. To overcome this problem, two approaches could be used. The first one corresponds to EDF (French Electricity Board) experience which states that the rotor temperature is $10^{\circ} \mathrm{C}$ greater than the stator one [6]. The second approach is based on Kubota work in [7]. In this case, the stator resistance is deduced from

$R_{s}=k R_{r} ; \quad k=\frac{R_{s n}}{R_{r n}}$

where $R_{s n}$ and $R_{r n}$ are the nominal values of stator and rotor resistance as given by the machine manufacturer.

The concept of estimating rotor temperature by back calculation from the motor slip is not new to machine designers. What is interesting in the proposed technique is the simple equation (7) for arriving at the rotor resistance. The principle of the proposed thermal monitoring technique is then illustrated by Fig. 2.

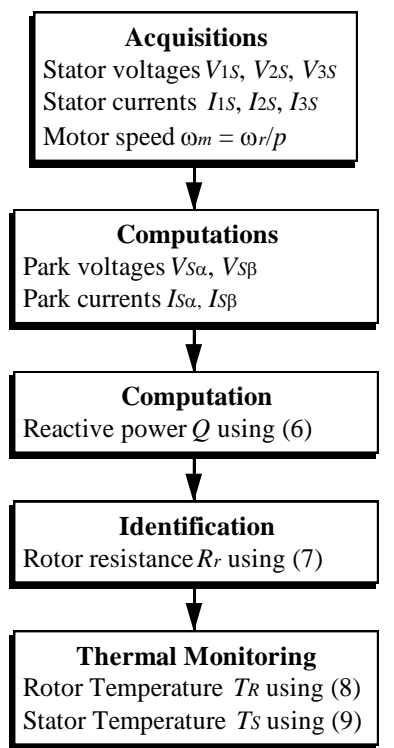

Fig. 2. The proposed induction motor thermal monitoring technique. 


\section{SIMULATION RESULTS}

The proposed identification technique has been simulated on a 4-kW four-pole squirrel cage induction motor which ratings are summarized in the appendix. The motor model is represented by (1) as well as the following mechanical equation.

$\dot{\omega_{m}}=-\frac{D}{J} \omega_{m}+\frac{3}{2} p \frac{M}{J}\left(i_{s \beta} i_{r \alpha}-i_{s \alpha} i_{r \beta}\right)-\frac{T_{l}}{J}$

where $D(0.001 \mathrm{~N} \cdot \mathrm{m} \cdot \mathrm{s})$ is the viscosity resistance, $J(0.024$ $\mathrm{kg} \cdot \mathrm{m}^{2}$ ) the total inertia, $p$ the pole pairs number and $T_{l}$ the load torque.

The validity of the proposed identification technique is well verified by simulations as illustrated by Figs. 3 and 4 . These results are obtained for a light load condition at 1482 $\mathrm{rpm}$, where the identified resistance is $R_{r}=1.45 \Omega$ comparing to the real value $R_{r}=1.44 \Omega$ and for a load torque at 1460 $\mathrm{rpm}$, where the identified resistance is $R_{r}=1.44 \Omega$.

Moreover, the identification method has been tested for a specific case where the real rotor resistance is given an exponential profile.

$R_{r}(t)=R_{r 0}+\left(1-e^{-1.2 t}\right)$

where $R_{r 0}=1.44 \Omega$.

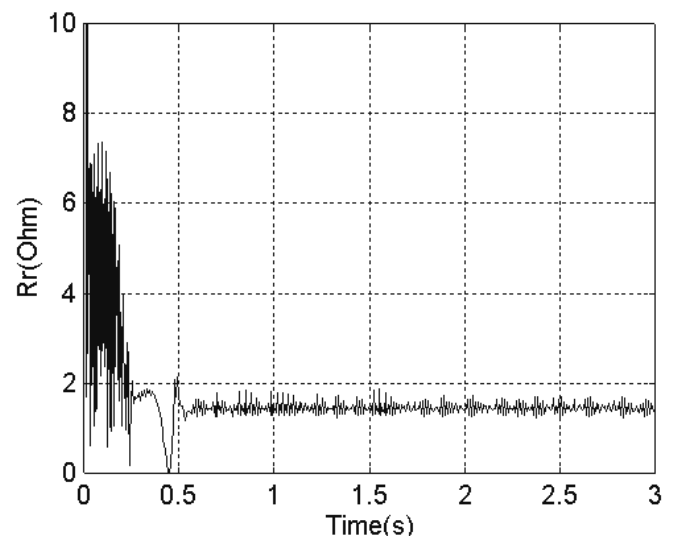

Fig. 3. Rotor resistance identification for a load corresponding to $1482 \mathrm{rpm}$.

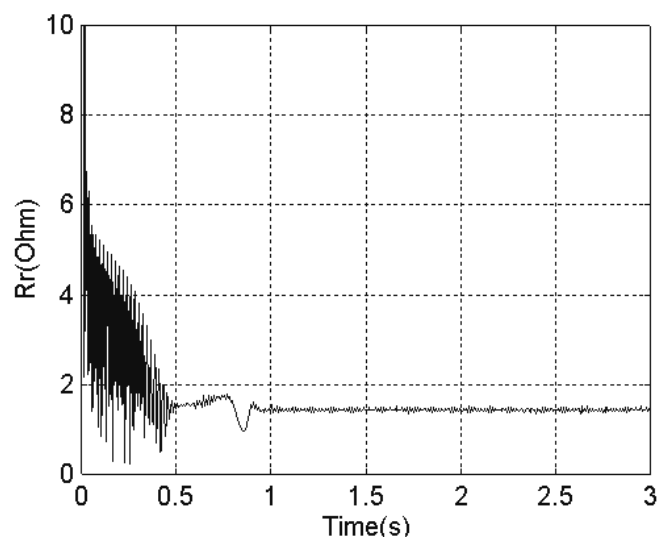

Fig. 4. Rotor resistance identification for a load corresponding to $1460 \mathrm{rpm}$.
Figure 5 shows a quite good identification of the rotor resistance profile.

\section{EXPERIMENTAL RESULTS}

\section{A. Experimental Benchmark}

The proposed thermal monitoring technique has been tested on 4-kW squirrel cage induction motor with dc generator coupled on its shaft. Figures 6 and 7 show a view and a schematic description of the experimental set up.

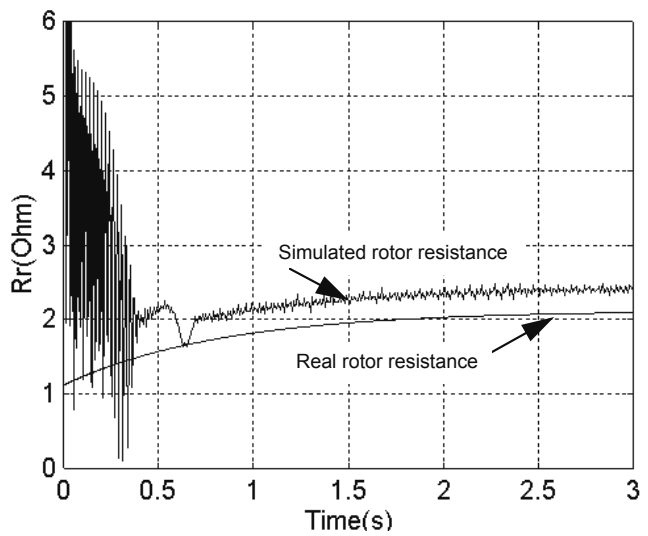

Fig. 5. Exponential profile rotor resistance identification

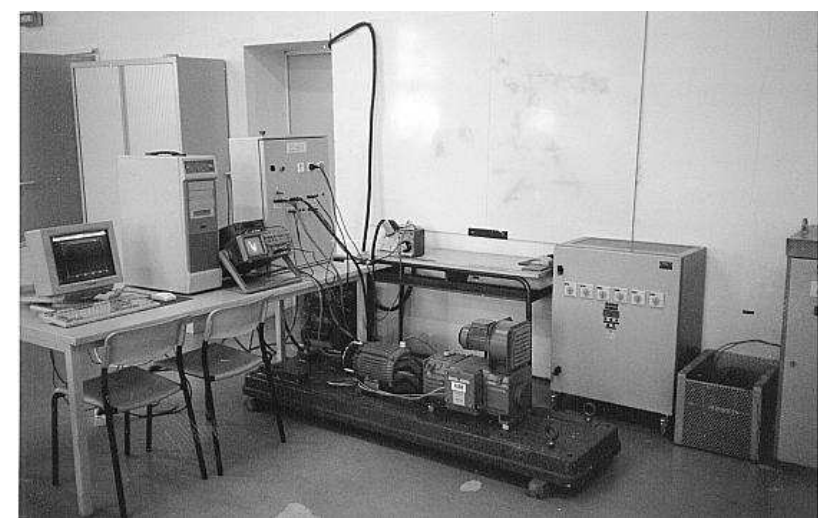

Fig. 6. View of the experimental set up.

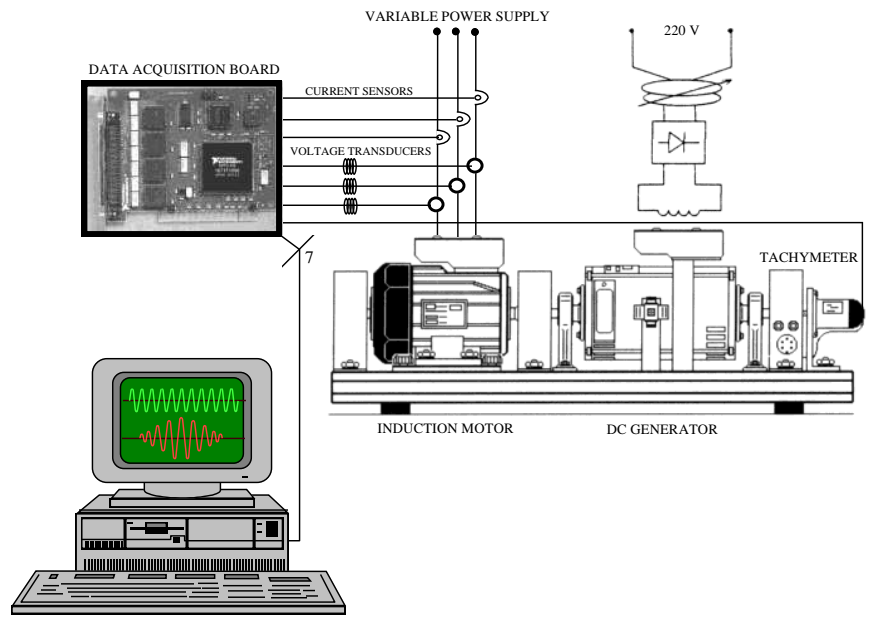

Fig. 7. Schematic description of the experimental set up. 


\section{B. Experimental Results}

Figure 8 shows experimental results of the rotor resistance identification for a load corresponding to $1482 \mathrm{rpm}$. Then, Fig. 9, as for Fig. 8, illustrates specific identification processes of the rotor resistance for $1460 \mathrm{rpm}$, where each curve corresponds to a resistance identification done $5 \mathrm{~min}$ after the previous one; from the induction motor starting until one hour operation. These figures illustrate clearly that the identification process is quite satisfactory.

The identification process convergence has been experimentally tested by varying the rotor resistance initial value $(4,-4,12$, and $-12 \Omega)$. As illustrated by Fig. 10, the identification process converges quickly and independently of the rotor resistance initial value.

The results of rotor temperature estimation, using (8), are illustrated by Figs. 11 and 12. Estimated rotor temperature is, in this case, in good agreement with induction machine classical theory. In fact, one should note that the magnitude of the temperature differential increases with the load level. More, for the thermal monitoring of the induction motor (rotor and stator), we have used (9) to estimate the stator temperature: this is in a good concordance with [6].

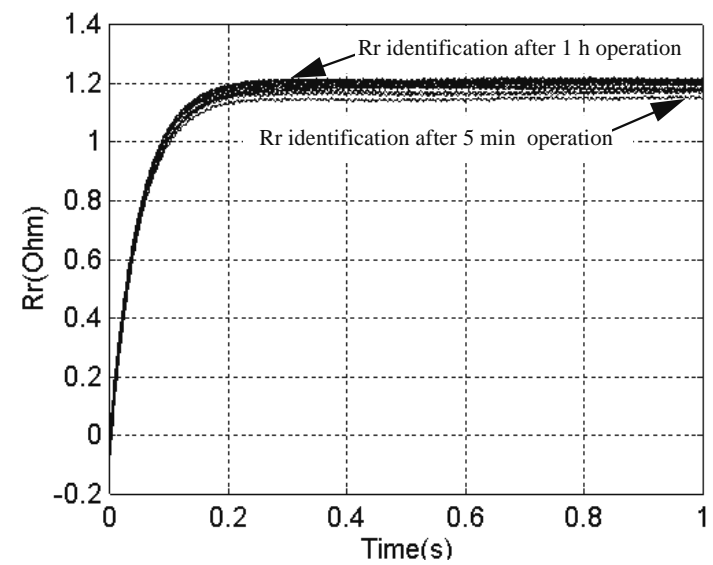

Fig. 8. Rotor resistance identification for a speed of $1482 \mathrm{rpm}$.

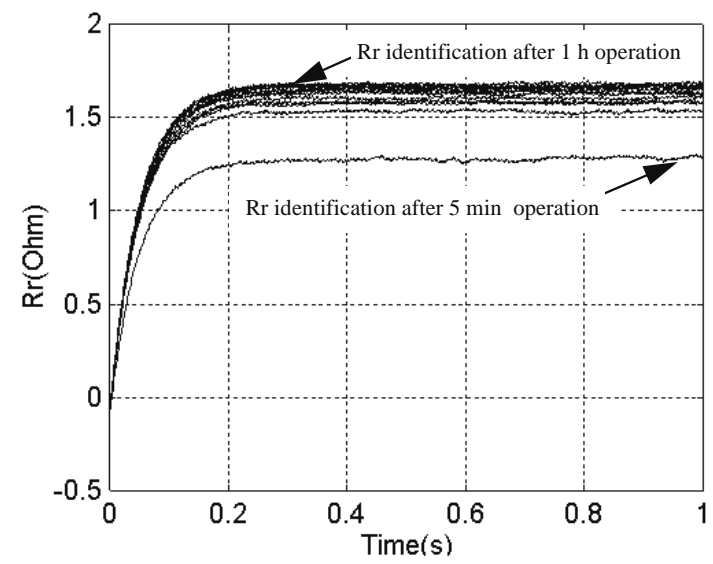

Fig. 9. Rotor resistance identification for a speed of $1460 \mathrm{rpm}$.
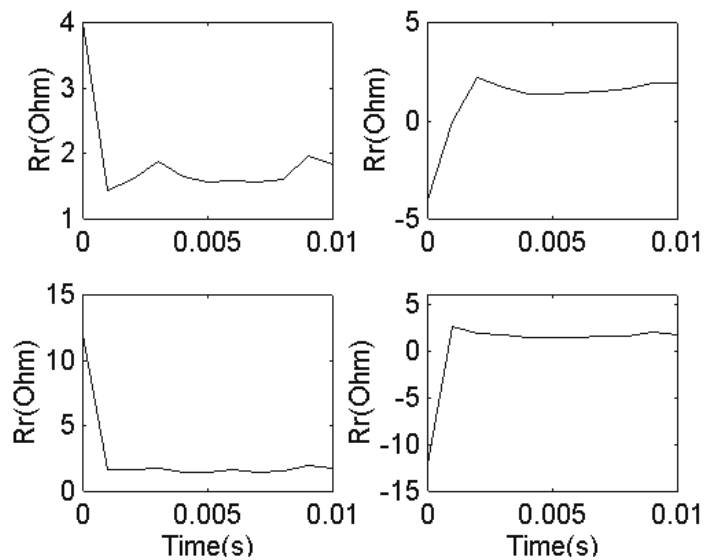

Fig. 10. Convergence of the identification process.

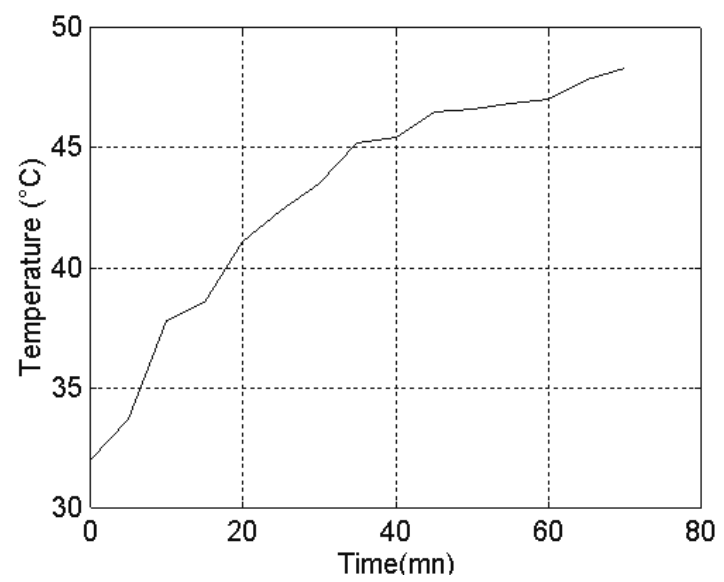

Fig. 11. Estimated rotor temperature for a load corresponding to $1482 \mathrm{rpm}$.

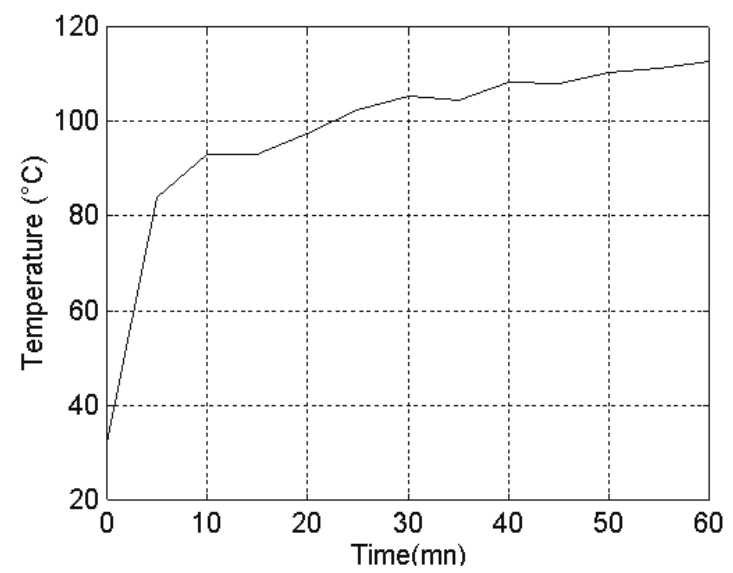

Fig. 12. Estimated rotor temperature for a load corresponding to $1460 \mathrm{rpm}$.

\section{CONCLUSION}

The viability of induction motor thermal monitoring using only rotor resistance identification has been investigated. Experimental results, for a $4-\mathrm{kW}$ four-pole squirrel cage induction motor, show the industrial feasibility of the proposed technique. However, extensive experimental studies are necessary to full assess usefulness of the proposed thermal monitoring technique for larger industrial machines. 
Apart from its benefits as a rotor condition monitor for induction machines on a long-term basis, such a technique can be an effective tool for machine designers and protection system designers, who are concerned about induction machine temperature monitoring.

\section{APPENDIX}

\section{PARAMETERS OF THE MACHINE UNDER TEST}

\begin{tabular}{llll}
\hline Rated values & Power & 4 & $\mathrm{~kW}$ \\
& Frequency & 50 & $\mathrm{~Hz}$ \\
& Voltage $(\Delta / \mathrm{Y})$ & $220 / 380$ & $\mathrm{~V}$ \\
& Current $(\Delta / \mathrm{Y})$ & $15 / 8.6$ & $\mathrm{~A}$ \\
& Speed & 1440 & $\mathrm{rpm}$ \\
Constants & Pole pair $(p)$ & 2 & \\
& $R_{S}$ & 1.150 & $\Omega$ \\
& $R_{r}$ & 1.440 & $\Omega$ \\
& $l$ & 0.013 & $\mathrm{H}$ \\
& $\alpha$ & 0.143 & $\mathrm{H}$ \\
& $\alpha(\mathrm{Cu}$ or $\mathrm{Al})$ & 0.004 & $1 /{ }^{\circ} \mathrm{C}$ \\
\hline
\end{tabular}

\section{REFERENCES}

[1] A.H. Bonnett and G.C. Soukup, "Cause and analysis of stator and rotor failures in three-phase squirrel-cage induction motors," IEEE Trans. Industry Applications, vol. 28, n²4, July-August 1992, pp. 921-937.

[2] K.R. Cho, J.H. Lang and S.D. Umans, "Detection of broken rotor bars in induction motors using state and parameter estimation," IEEE Trans. Industry Applications, vol. 28, n³, May-June 1992, pp. 702-709.

[3] R.R. Schoen, B.K. Lin, T.G. Habetler, J.H. Schlag and S. Farag, "An unsupervised, on-line system for induction motor fault detection using stator current monitoring," IEEE Trans. Industry Applications, vol. 31 , $\mathrm{n}^{\circ} 6$, November-December 1995, pp. 1280-1286.

[4] R.R. Schoen, T.G. Habetler, F. Kamran and R.G. Bartheld "Motor bearing damage detection using stator current monitoring," IEEE Trans. Industry Applications, vol. 31, n6, November-December 1995, pp. 1274-1279.

[5] C.C. Chan and H. Wang, "An effective method for rotor resistance identification for high-performance induction motor vector control," IEEE Trans. Industrial Electronics, vol. 37, n6, December 1990, pp. 477-482.

[6] M. Dessoude, Electricité de France (EDF), R\&D Division, Electrical Equipment Department (France), Personal Communication, June 1994.

[7] H. Kubota, K. Matsuse and T. Nakano, "DSP-based speed adaptive flux observer of induction motor," IEEE Trans. Industry Applications, vol. 29, n², March-April 1993, pp. 344-348.

\section{BIOGRAPHIES}

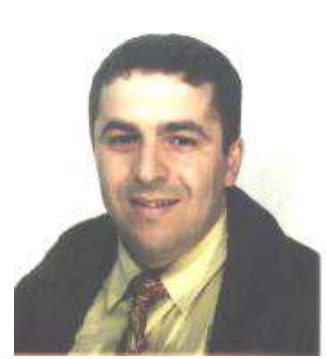

Rachid Beguenane (M'96) was born in TiziOuzou, Algeria, on September 28, 1965. He received the $B . S c$. degree in Electronic Engineering, in 1988, from the Electronic Institute of Algiers Technological and Sciences University, Algeria; the M.Sc. degree in Physical Systems and Metrology, in 1991, from the Metrology National Institute of Paris, France; and finally the Ph.D. degree also in Physical Systems and Metrology from the Conservatoire National des Arts et Métiers, Paris, France. After graduation, he joined the University of Picardie - Jules Verne, France, where he hold a Teaching and Research Position at the Professional Institute of Amiens. His is actually a Research Assistant at the School of Information Technology and Engineering of the University of Ottawa, Canada. His research activities are leading to the development and the improvement of new scheme for the control of electrical machines and drives. Dr. Beguenane has published more than 20 technical papers. He is a member of the French Society of Electrical Engineers SEE.

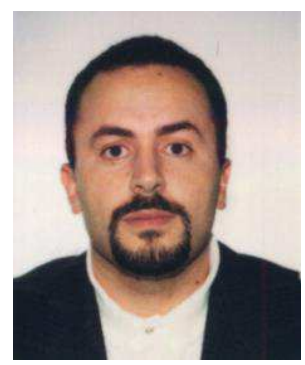

Mohamed El Hachemi BENBOUZID (S'92M'94) was born in Batna, Algeria, on January 3 , 1968. He received the B.Sc. degree in Electrical Engineering, in 1990, from the Electrical Engineering Institute of Batna University, Algeria; the M.Sc. degree in Electrical and Computer Engineering, in 1991, from the National Polytechnic Institute of Grenoble, France; and finally the Ph.D. degree also in Electrical and Computer Engineering, in 1994, from the National Polytechnic Institute of Grenoble, France. After graduation, he joined the University of Picardie - Jules Verne, France, where he is Associate Professor of Electrical and Computer Engineering at the Professional Institute of Amiens. His current research interests include electric machines and drives, computational of electromagnetics, and electromechanical actuation, as well as technics for energy savings. He is actually leading a research program on the monitoring and the diagnostics of induction machine drives for the French Picardie Region. Dr. Benbouzid has published more than 40 technical papers including 12 refereed publications in journals. He is a member of the French Society of Electrical Engineers SEE. He is active in PES-IEEE, and is the treasurer of the French Chapter of the PELS-IEEE. 